\author{
Sustinere \\ Journal of Environment and Sustainability \\ Volume 3 Issue 1 (2019) 1-13 \\ Print ISSN: 2549-1245 Online ISSN: 2549-1253 \\ Website: https://sustinerejes.comE-mail: sustinere.jes@iain-surakarta.ac.id
}

\title{
REVIEW \\ Conceptualizing sustainability in the real estate development process
}

\author{
Upuli Perera1 $^{1}$, Collins Adjei Mensah ${ }^{2}$ \\ 1. Department of Estate Management and Valuation, University of Sri Jayawardenepura, Sri Lanka \\ 2 Department of Geography and Regional Planning, University of Cape Coast, Ghana \\ Article history: \\ Received: 18 November 2018 | Accepted: 13 April 2019| Available online 30 April 2019
}

\begin{abstract}
Operationalizing sustainability within the real estate development is a challenge as such development process is complex, multidisciplinary in nature and involves multiple agencies. The paper, therefore, aims at strengthening the conceptualization of sustainability within the real estate development process (REDP) to address this challenge effectively. Adopting the systematic review, 127 publications focused on sustainability and REDP were appraised. Focusing on the institutionalist viewpoints, sustainability was found to be a problem driven notion which is socially constructed. Therefore, it requires to be viewed within the larger picture of agency, structure and power in the context of economic, social and environmental uncertainties. These are found to be applied in the same way in the contemporary REDP literature too. On account of this, the paper suggests, conceptualizing sustainability within REDP needs the latter to take into account the agency dynamics of actors in the development process such as agency motivation (values) to offer a meaningful operationalization of the concept. In other words, this paper calls for significant stakeholder participation in the REDP which allows significant levels of economic, social and environmental values of actors to be brought forward to build consensus to determine as to what is sustainability within it.
\end{abstract}

Keywords: Sustainability, Real Estate Development Process, Institutional Approach

\section{Introduction}

The real estate development process (REDP) helps to shape our built environment and the way people live and work, and thereby determines and enables human activity to evolve (Squires \& Heurkens, 2014). It is a process that makes decisions on the natural capital stock in the world. As the world is rapidly urbanizing - 54 percent of the world's population lived in urban areas in 2014 and it is expected to increase by 72 percent by 2050 (United Nations et al., 2014) - more and more natural capital stocks will be utilized for real estate developments to support urban living and work. On these grounds, for any real estate development project, sustainability is a major goal (Özkaynak et al., 2014; Pearce et al., 1989) to ensure effective 
utilization of those resources, because sustainable REDP serves as a primary catalyst to achieve sustainable development of economies.

The real estate development is a process that is complex, time-consuming, capital intensive, multi-disciplinary, externality-generating (Kohlhepp, 2018) and involving multiple agencies make operationalizing sustainability within the real estate development process a challenge. It requires much more than constructing 'green buildings' (Kauko, 2017). Urban areas across the world have high-tech green buildings followed by urban Utopia with the assumptions that in attaining sustainability people should be in adherence to those prescribed solutions provided by developers and planners. However, as pointed out by many scholars, such approaches have often been challenged in the light of operationalizing sustainability, owing to issues related to affordability and social acceptance (see for example; Horton et al., 2015; Walker, 2012; Checker, 2011; Bagheri \& Hjorth, 2007).

Whilst the concept of sustainability is co-evolving since the publication of the Brundtland report on sustainable development (World Commission on Environment Development, 1987), the Institutionalist Approach is considered to be the new way of understanding the concept in recent times. The Institutionalist Approach looks at the world in a relational view (Healy, 2007). It does not only looks into the structures or outcomes of processes but also takes into account different agency actors, their power relations and the time-space dynamics that shape and alter those structures and outcomes. Thus it is an approach that can help in understanding the cause and effects of complex processes such as REDP without concentrating on only one element over the others.

Using the imperatives of the Institutionalist Approach, this paper aims at strengthening the conceptualization of sustainability within the real estate development process (REDP) to effectively address contemporary complexities and challenges associated with the REDP. This effort will help policymakers, investors and developers, and the end-users of real estate to contribute in diverse ways to put the natural capital stock into good use to produce, create value, distribute and utilize real estate in a sustainable manner.

\section{The Institutionalist Approach}

The Institutionalist Approach argues that the social problems in this world need to be understood in a relational context (see for example Healy, 2007). The approach is now being used in a range of disciplines: sociology, economics, organizational studies, urban and regional planning, and public policy management (Healey, 1999). Here, "institutions" are not understood just as an organisation but as an established way of understanding and addressing social issues (Healey, 1999). Thus the approach is grounded in a socially constructed view of social life. Whilst the evolution of this approach can be traced back to the Marxist political economy (Healey, 1999; Lowndes, 2010), the current framework of the approach is much attributed to Anthony Giddens' Theory of Structuration and the Habermas' critical theory for communicative actions.

According to Giddens, structures are rules and resources. Human beings are purposive agents that carry motives (values), and their actions occur as a duree (duration), a continuous flow of conduct as recursive practices which presume to have reflexivity (Giddens, 1984). Moreover, these agency values and actions are driven by knowledge (the intellectual virtues and 
associated believes that such knowledge is true; Cassam, 2009) embedded within agents. A social structure (or 'institution) is a reflexivity of the agents' actions. In this context, agency and structure are not two independently given sets of phenomena but present a duality (duality of structure). If so, as claimed by Giddens, the structural properties of social systems such as "sustainability" in REDP are both the medium of agency and the outcome of the practices they recursively organise. Systems such as sustainable real estate development processes are formed if these interactions are reproduced (with power relations) into patterns of social relations (Giddens, 1984).

Giddens borrowing from Hägerstrand's (1976) trans-disciplinary perspective -the effect of time-space, states that these systems and structures (or institutions) are not static but subject to change by agent's actions. Therefore it is the experience of these social relations that linked to different time and space shapes the individual identities and provides implicit and explicit ontological principles of life. These understandings altogether shaped the Institutionalist Approach to claim that structures and systems in the social world are socially constructed, challenging the conventional imaginations of society that actors within systems operate normatively with prescribed preferences at all times (Giddens, 1984).

The Institutionalist Approach was further shaped by Habermas' critical theory for communicative actions and later by works of planning theorists such as John Friedmann, Charlie Hoch and Judy Innes. Critical theory argued how the above-stated social interactions of actors that carry different values should be governed to create structures: for instance, in a particular planning process such as REDP to generate structures and systems of meanings, such as "sustainable" real estate development outcomes. The common idea shared by these theorists suggests that all actors' values form different reasoning or stored knowledge, therefore those should be allowed for articulating, debating, disseminating and be used to create "systems of the world" (Healey, 1999). This apprehended the emotive reasoning of the agency at the same level as instrumental or scientific reasoning. In sum, the institutional approach promotes multidimensional and integrated policy developments having the aim of people making sense together but living differently (Healey, 1999).

\section{Methodology}

The focus of the study is a conceptual synthesis of the concept of sustainability in general and sustainable REDP in particular made the systematic review approach an ideal methodological option to consider. It is an approach that entails the usage of an explicit approach to search, appraise and synthesize available literature to satisfy the aim of the topic under study (Berrang-Ford et al., 2015; Victor, 2008). Using this approach helps to avoid bias in the results of the study and assists in providing a more reliable synthesis to draw informed conclusions as the approach uses data that have already been empirically tested in other studies. For the review process to be in a systematic, transparent and reproducible manner (Tranfield et al., 2003) the study adhered to the following prescribed processes (see for example Bryman, 2012):

(i) Define the purpose and scope of the review and the accompanying relevant materials Given the scope of the study which covers the conceptualization of sustainability within the REDP, the paper relied on published materials related to both sustainability and REDP in academic databases such as Google Scholar, Science Direct, Social Science Research 
Network, Directory of Open Access Journals (DOAJ), Scopus, JSTOR, Ingenta Connect, Elsevier and Web of Science. In addition to this, search engines such as Google, Yahoo, Bing and Ask.com were also searched for further materials. Altogether a total of 487 relevant publications were found at this stage.

(ii) Appraise the publications according to the purpose of the paper- The total relevant publications arrived at the second stage were further reduced down to 127 publications for final inclusion in the study. In doing this, the publications were first narrowed down to studies published with respect to The Organisation for Economic Co-operation and Development (OECD) countries as those were the context in which this paper focuses on economies that are developed, support markets and thus utilizes significant resources for real estate. Thereafter, those publications that focused on the field of study of the paper in terms of theoretical underpinnings of the paper and offers a conceptual understanding of sustainability, institutionalist approach and REDP were considered (Bowler et al., 2010).

(iii) Synthesizing the results - Rigorous content analyses were conducted on the finally selected publications. The findings from these analyses were then collated and used to discuss various sections of this paper. Accordingly, the paper first reviews the co-evolution of both sustainability and REDP models, and its links with the institutionalist approach. Thereafter, it argues for the adoption of the institutionalist approach to conceptualize how sustainability can be embedded into REDP.

\section{Results}

\subsection{Conceptualizing sustainability}

The concept of sustainability is an evolution (Glavič \& Lukman, 2007). The recent concerns for sustainability emerged in 1960-1970s as a reaction to the degradation of the environment and well-being of the societies in the post-war new economies of industrialized countries or what otherwise known as OECD countries (Filho, 2000; Wood, 2005). The accelerated economic development during the post war periods and neo-liberalization has induced changes to the environment and resource consumption patterns (in a negative manner). In view of this since the late 1970s, there has been a rise in environmental movements lobbying for "sustainable development". Such lobbying called for an eco-centric view of the world: economic actions being responsible for the negative influences on natural environments and future societies (Glavič \& Lukman, 2007).

The first officially recognized definition for sustainability was declared by Brundtland Report published by United Nations World Commission on Environment and Development (WCED) (1987), stating "....economic growth can and should be managed in such a way that the quality of life of future generations is ensured". This definition tagged sustainability into three well-known fundamental principles of sustainability. i.e. the economic principles, environmental principles and social principles. According to the Brundtland Commission's paper (Our Common Future), the economic principles are to deal with "needs", environmental principle to focus on "limits" for production and consumption, and social principles to ensure "equity" among societies. The literature developed on sustainability thereafter shows this basic idea of sustainability, in use, has been translated into two main trajectories. First, carrying forward this initial definition to classify or assess developments as "sustainable or not" in which this paper labels them as the normative approaches. The second is the institutionalist view: the studies that attempt to be more critical to confront the operationalizing challenges of sustainability. 
Sustainability trajectory 1 - normative approaches: The first trajectory, here known as normative approach, primarily follows the outset definition provided in the Brundtland's Report. Under this, sustainability has been mostly described as a 'three-pillar' issue (Figure 1Above). This is recognized as a normative approach, being prescriptive and standardizing the criteria that form economic, social and environmental sustainability interfaces. The application of these criteria has been primarily to assess developments in the light of economic sustainability, environmental sustainability and social sustainability. For instance, Šaparauskas and Turskis (2006) suggest, sustainability in the construction industry can be indicated through - number of dwelling completed, public building completed, labour productivity in construction, gross value added and gross domestic product in construction, final energy consumption in construction and energy intensity in construction as requirements to ensure economic, environmental and social sustainability. In a similar vein, Chiu (2004) discussed the sociocultural sustainability of housing as having (a) the social preconditions conducive to the production and consumption of environmentally sustainable housing; (b) equitable distribution and consumption of housing resources and assets; (c) harmonious social relations within the housing system; (d) an acceptable quality of housing conditions; and (e) preservation of housing heritage, likewise. Such criteria underpinned by objectivism made studies focusing on them to follow quantitative research strategies thus requiring sustainability to be viewed within a measurable set of variables. Thus the criteria set were assumed to be normative and mutually exclusive from one another. Such methods were widely applied and consequently meant to be the mainstream literature reading on sustainable development (Vos, 2007).

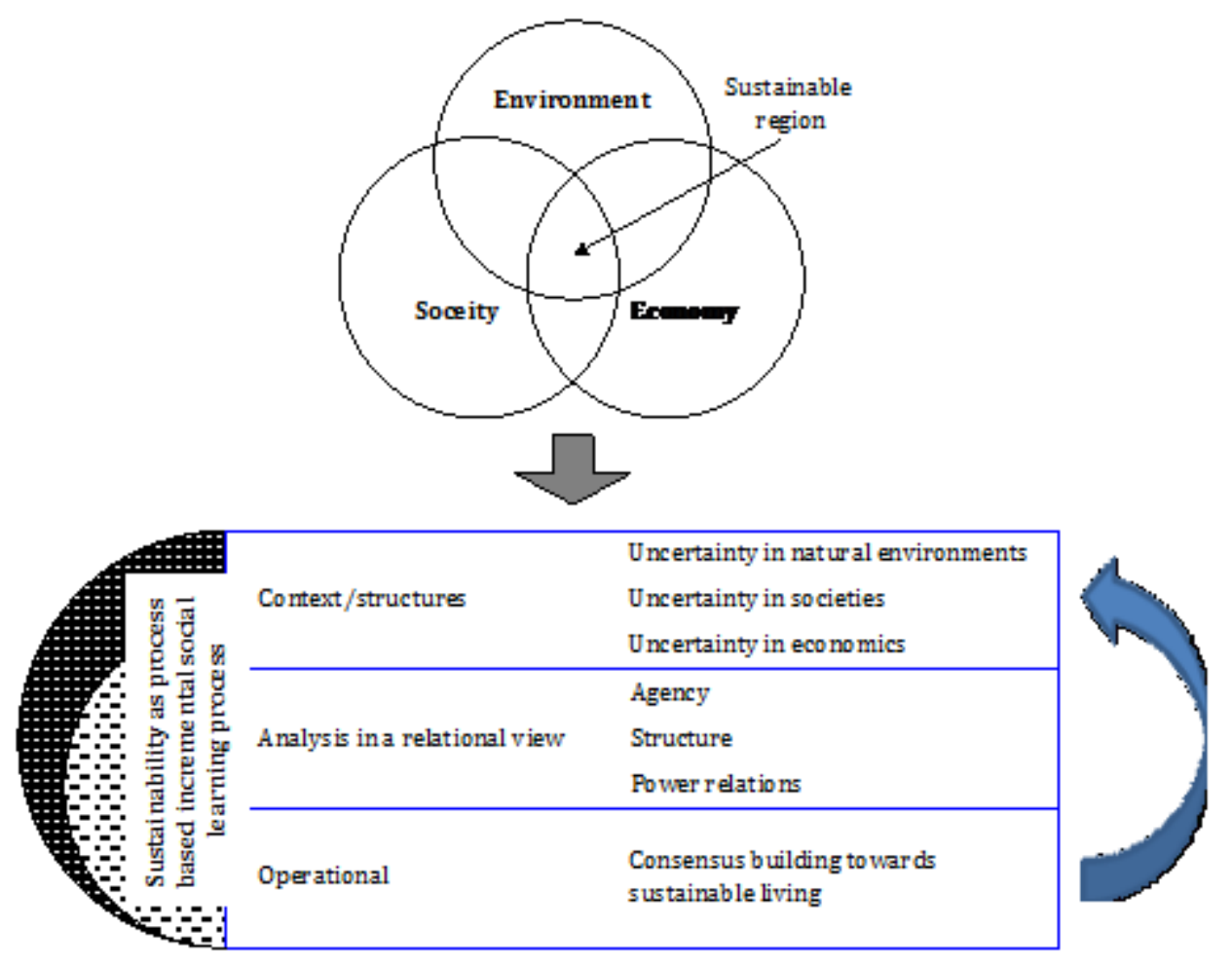

Figure 1. The conceptual shift of sustainability towards institutionalist viewpoints. Above: the normative view; interlocking rings of three pillars of sustainability interfaces having the assumption that sustainable development is achieved when these three interfaces overlap; Bottom: A nested model removing the nebulous distinction between the economic, environmental and social interfaces and seeing sustainability is socially constructed thus process based (Source: Author construct, 2019). 
These mainstream literatures have helped to popularize and inculcate the awareness of the sustainability concept in the mindset of society. However, at the operationalizing of the concept, the ignorance of complex relationships among those variables and the uncritical assumptions that the sustainability can be ultimately achieved through technological fixtures-green technology and policy fixtures (Lombardi et al., 2010; Vos, 2007) have shown limitations. For instance, "sustainable practices being a cliché" (Walker, 2012); hypocrisy: fake greenery, delusion (Robinson, 2004); absurdness of designs (Horton et al., 2015); environmental gentrification (Checker, 2011; Curran \& Hamilton, 2012), etc. Such critics highlight that the standard frames of reference for sustainability have become elusive at the time of operationalizing the sustainability notion. Largely based on laissez-faire economics ideology, the underlining principles that generate norms for social and environmental sustainability have been looking in the mirror of how far the economic activities cause market inefficiencies and failures (Costanza et al., 1997). The context that Brundtland's definition got published was first to popularize the concept of "sustainability" through governments and businesses and hence was presented in a romantic style (Robinson, 2004). Thus, the way forward for sustainability concept to have a meaningful operationalization cannot be warranted through uncritical assumptions placed on these normative definitions.

Sustainability trajectory 2 - institutionalist approach -The critiques for the mainstream definition of sustainable development created a point of departure from the normative approach towards an alternative way of viewing sustainability - understanding sustainability in the light of social constructionism driven institutionalist approaches. In the literature, this trajectory seemed to be particularly sprung up from mid-2000 onwards and meant to view sustainability from the cultural and political perspective, inextricably tied to prevailing values and beliefs in the society (Glavič \& Lukman, 2007; Matutinović, 2007). Highlighting how the concept of sustainable development dwelled in industrialized countries since 1987, Robinson's (2004) argued that sustainability is "ultimately an issue of human behavior and negotiation over preferred futures, under conditions of deep contingency and uncertainty". Discussing the critics and the concerns of past praxis of "sustainability" he indicated that sustainability is largely a problem which is socially driven and constructed. It is socially constructed because, "sustainability" in development reflects the social consensus about what is "sustainable" or "unsustainable" development, and therefore cannot be translated into a blueprint or a defined end (Voss et al., 2007). The (sustainability) science may help to identify directions in which changes are needed, but it does not guarantee new trajectories for sustainability (Kemp \& Martens, 2007).

This view of sustainability makes the institutionalist view to have the vocabulary of relationships between the structures, agency, their power relationships and time-space dynamics, thus acknowledging that it is a concept which is socially constructed. This has now being embraced in policy language, for instance, the European Union (European Union, 2004) defined sustainable urban design as a process whereby "all the actors involved... work together through partnerships and effective participatory processes to integrate functional, environmental, and quality considerations to design, plan and manage [the] built environment". Invariably, the five guiding principles of "UK Sustainable Development Strategy Securing the Future" included good governance - engaging people's creativity, energy, and diversity, - as one such primary principle of sustainability. Furthermore, the primary driver for UK planning reforms 2010 was to enact localism (Localism Act 2011) in order to empower local communities and local government in the real estate development process. Moreover by 2016, United Nations in its Sustainable Development Agenda for 2030 (United Nations, 2016) expanded it's previous Brundtland's version of sustainability into 17 goals of Sustainable Development Goals based on different world problems whilst goal 17 recognizes the stakeholder partnerships and engagement of all actors as a means to achieve the rest 16 sustainability goals. 
Brundtland's view of normative definitions for sustainability focuses on structures. The institutionalist approach argues that structures are not isolated but shaped by the actions of stakeholders and the power relationships associated with those actions - socially constructed. Consequently, sustainability is subject to time-space dynamics - agents interests are changing. On this basis, operationalizing sustainability is about dealing with uncertainties over time-space and developing consensus among various stakeholder interests. It is these interests that carry values (i.e. criteria) for economic, environmental and social sustainability.

Figure 1-bottom shows this shift of understanding which is the second trajectory of sustainability conceptualization in a graphical form - sustainability towards a dual nested model. Accordingly, on the whole, the institutionalist approach to sustainability purports three basic elements to understand and operationalize sustainability. Firstly, recognizing that tensions or uncertainties arouse in environmental, social and economic worlds are structures that are linked up with different agency actions. Here, environmental, social and economic worlds do not have clear boundaries- those are integrated and have fuzzy boundaries. Secondly, the recognition that causation to these tensions is linked with agency actions would also mean that they are inexorably driven by agency values (embedded knowledge) and power relations. Thirdly, on account of the first and the second, sustainability to be achieved through mobilizing these agency values and power relations towards consensus building with respect to the uncertainty concerned. In other words, problem (tensions) solving through reflexive mode of governance by engaging communities and collaborative planning (Blewitt, 2014; Kemp \& Martens, 2007; Ramasubramanian, 2010; Robinson, 2004). This consensus building has to be proactive to grasp local knowledge to work in the direction of what sustainability science has been suggested in addressing a particular issue (Næss, 2001; Schreurs \& Moulaert, 2014). It should not be to destroy everything together but to build alliances towards a common goal of sustainable living (Næss, 2001; Schreurs \& Moulaert, 2014). This element, on the other hand, provides a point of entry for the sustainability science (apprehend by the previous approaches) to remain within the institutional approach. Having recognized that sustainability is process-based rather than endpoint oriented fixed goal (Bagheri \& Hjorth, 2007; Robert Costanza \& Patten, 1995), the model acknowledges that the future uncertainty and adaptability and even the interests (i.e values) of actors themselves are changing. Therefore, to achieve sustainability, all communities having a stake in development should be allowed to engage in consensus building for an incremental social learning process. This institutionalist view differs from that of normative approach which assumes, sustainability can be achieved as a one-off delivery.

\subsection{REDP models and turns for intuitionalist approach}

REDP is the catalysts to operationalize sustainability in the built form. This section reviews the way in which REDP is explained within contemporary studies, to understand, how parallel it is with the co-evolution of the sustainability concept. This forms the basis to identify gaps and to analyze how sustainability can be conceptualized within the REDP.

The present literature explaining REDP can be primarily classified into (i) equilibrium models (ii) event-sequence models (iii) agency models (iv) structural models and (v) institutional models (Adams \& Tiesdell, 2012; Healey, 1991; Ratcliffe et al., 2003; Squires \& Heurkens, 2014).

The equilibrium REDP models focus on demand and supply of real estate (Healey, 1991, 1992). In other words, whether the development has brought in sufficient supply to meet the demand, which is often associated with the real estate adage, "at the right place at the right time" (Healey, 1991). The analysis of REDP here is translated into analyzing of rents and yields, land and building valuation, driving the assessment focus on returns and losses (Healey, 1992). The event sequence models on the other hand appreciate the timescale complexities of the REDP. 
With its neo-classical economic traditions (Healey, 1991) it unpacks the development process into constituent events. Some examples include Cadman and Austin-Crowe (1978) who divided the process into (i) evaluation (ii) preparation (iii) implementation and (iv) disposal. Another notable example is Miles et al.'s (1996) classification of the REDP into (i) inception of an idea (ii) refinement of the idea (iii) Feasibility (iv) contract negotiation (v) formal commitment (vi) construction (vii) completion and formal opening (viii) asset and property management and so on. The models scope therefore translated the analysis of the REDP into distinguished steps to understand the relationships between different stages (Ratcliffe et al., 2003) and the social relations of actors surrounded in each event (Healey, 1991). The agency model places the actors or otherwise stakeholders at the center of the REDP analysis. This approach emphasizes the distinction between actors, their roles and the power relations in the development process. For instance, whilst the developer becomes the primary actor in the development process, his or her role as the coordinator of resources and catalyst in the development process (Craven, 1969; Drewett, 1973; Kaiser \& Weiss, 1970) largely determines the outcomes of the real estate development. The structural models, rooting back to Marxist ideologies nurtured in the urban political economy literature (Healey, 1991), analyses how different markets are structured through power relations of capital, labor and landowner. The analysis of scholarly works that followed structural models for REDP (Amborse, 1986; Ball, 1983; Boddy, 1981; Harvey, 1982, 1985; Holland et al., 2002; Massey \& Catalano, 1978) highlight that this model is particularly useful in seeking how a certain policy (or policy change) affects the flow of different forms of capital and surplus generations between developers, state sector, industry and so on.

Since all those models particularly place the analytical emphasis on a selected typology (i.e. demand and supply, events, actor's interests, power relations or structures ) whilst leaving the contexts of unselected typologies as dummy variables (Healey, 1991), institutionalist views have penetrated into the REDP to fill in those gaps.

Institutional model of REDP: The institutional model to analyze the real estate development process (REDP) was pioneered by Pasty Healy a British Town planner and an emeritus professor. In 1992 in her paper published on "An institutional model of the development process" recognized that the REDP is complex; bounded by events involved in the project, agency varieties, their roles and activities, and general tendencies in social relations of the development process in ways which connect to macro-economic and political questions, spatial and temporal variations (Healey, 1991). As a result, the institutional model for REDP was developed by combining all the variables that had been identified in the previous models. Instead of focusing the analysis on a specific typology, this approach proposes all variables related to previous typologies to consider at distinguishing levels of REDP analysis.

As shown in Figure 2, the first level of analysis is the empirical observation level: recognition of concrete events, agencies involved and their power relations evolve between them. In other words, it is the stage where the societal problems and needs are recognized. The second level of analysis is the assessment of strategies and interest of actors related to resources, rules and ideas governing the development process. The third level is the level that makes the connection with the social relations expressed in the prevailing model of production as the mode of regulation and ideology of the society within which development is being taken place.

With similar variables like that of sustainability models, the institutional model of REDP showed an evolution in a similar direction. Over the period, the institutional model of REDP had been co-evolving in the research agenda of real estate planning and development. For example, Adams and Tiesdell (2012) employed the institutional model of REDP to analyze the property industry in the UK. Squires and Heurkens (2014) employed it to understand the real estate approaches across various international real estate markets. Doak and Karadimitriou (2007) on 
the other hand presented a conceptual framework to analyze REDP in the context of land redevelopment to reflect its complexities and networks.

\begin{tabular}{|c|c|c|}
\hline & \multicolumn{2}{|c|}{$\begin{array}{l}\text { 1. Material Values: Production, consumption, investment } \\
\text { 2. Property rights } \\
\text { 3. Guardian of environmental quality }\end{array}$} \\
\hline $\begin{array}{l}\begin{array}{l}\text { Factors of } \\
\text { Production }\end{array} \\
\begin{aligned} \text { 1. } & \text { Land } \\
\text { 2. } & \text { Labour } \\
\text { 3. } & \text { Capital }\end{aligned}\end{array}$ & $\begin{array}{l}\text { Events in the real estate development process } \\
\text { e.g. } \\
\text { Identification of development opportunities } \\
\text { Land assembly } \\
\text { Site clearance } \\
\text { Acquisition of finance } \\
\text { Organization of construction } \\
\text { Organization of infrastructure } \\
\text { Marketing/managing the end product }\end{array}$ & $\begin{array}{l}\text { Products/Outputs } \\
\text { - In the Building } \\
\text { 1. Material values } \\
\text { 2. Bundle of property rights } \\
\text { 3. Symbolic/aesthetic } \\
\quad \text { values } \\
\text { - In the production process } \\
\text { 1. Profits } \\
\text { 2. Jobs } \\
\text { 3. Demands for related } \\
\quad \text { goods/services } \\
\text { Impacts } \\
\text { Wider economic } \\
\text { Political, environmental } \\
\text { Sociocultural effects }\end{array}$ \\
\hline \multicolumn{3}{|c|}{ Roles in production } \\
\hline & $\begin{array}{l}\text { 1. Roles and relationships } \\
\text { 2. Strategies and Interests } \\
\text { 3. Rules-resources-ideas } \\
\text { 4. Mode of production } \\
\text { 5. Mode of regulation }\end{array}$ & \\
\hline
\end{tabular}

Figure 2. Institutional model of REDP. Source: Adopted from Healey (1992)

\subsection{Discussion: Conceptualizing sustainability in REDP}

The institutional approach explaining both sustainability and REDP highlights, both are problem driven. i.e; emerged to solve a particular issue in the social world. The review results of REDP literature showing that it has co-evolved in the same direction as sustainability indicates that in the contemporary discourse on developments, sustainability has become an obvious orientation. The concept of sustainability has reached a point of understanding that its associated problems are socially constructed, thus, a consensus building process would serve a good approach for probable solutions. At a similar level, the institutional model of REDP acknowledges a wider scale of variables to perform a deeper analysis of real estate outcomes. 
Combining these two together, the paper finally suggests, how the institutional model of REDP can be revived with the contemporary institutional view of sustainability to conceptualize sustainable REDP more explicitly.

Sustainable REDP recognizes problems through the lens of tensions within actor's (stakeholders) varying (i.e. conflicting) economic, environmental and social interests or values and power relations associated with a particular development. Sustainable real estate, therefore, would mean a particular development outcome status which complies with the best level of shared meaning that generated out of all stakeholder values. On this basis, a sustainable REDP promotes governance through collaborative planning to build consensus among different stakeholders to form sustainable development outcomes. It embraces the philosophy that agents' interests and values are knowledge. Each stakeholder's knowledge is provisional and not concrete (Kemp \& Martens, 2007) thus engagement and consensus building is a knowledge diffusion process that allows for, and reinforces, social learning and changes in views over time (Acemoglu et al., 2002; Robinson, 2004). Sustainable REDP has to demonstrate how this social learning process has an impact within the process and the process outcome. This on the other hand means, sustainable REDP is a non-linear process. The governance for collaborative actions to share mutual knowledge, therefore, is to apprehend the feedback loop nature of the knowledge dynamics conveying the lessons/experiences to decision makers - either via a deliberate or natural process, generating a new set of values for a sustainable trajectory. In other words, the meanings of sustainability come in trajectories, therefore, learning needs to be feedback into the next level of understanding in the production of real estate. The negative feedbacks self-correct the system towards sustainability (Bagheri \& Hjorth, 2007). Production of space (in this case real estate) is captured best as the complex articulation between structure and agency, which is always in motion (Gottdiener, 1994).

\section{Conclusions}

Both sustainability and REDP models have co-evolved to a level that those recognize the institutionalist view as a means to understand relevant problems and find solutions accordingly. It builds the argument that these concepts are socially constructed. Therefore, operationalizing sustainability in REDP requires one to see the relationship between the economic, social and environmental uncertainties in a given context with its' associated agency factors (i.e different stakeholder interests and their power relations). Thus a sustainable REDP is the best level of articulation of stakeholder interests that aims at generating the best level of shared meanings on sustainable development outcomes. This provides several lessons to policymakers and practitioners on REDP. Firstly, it helps them to acknowledge that stakeholder interests (values) associated with REDP as knowledge. Secondly, it makes them aware that sustainable REDP is an incremental process rather than a one-off delivery. Finally, based on the first and the second above, it informs them that achieving sustainable REDP requires the decision making for REDP (at all development stages) be governed by promoting knowledge creation, feedback loop dynamics and consensus building.

\section{Acknowledgement}

The first author's sincere gratitude goes to the Commonwealth Scholarship Commission (UK) and the supervisors of the PhD project in which this paper is partially based on. Sincere thanks to the second author for bringing a good discussion throughout to finish the paper. 


\section{References}

Acemoglu, D., Simon, J., Robinson, J., \& Thaicharoen, Y. (2002). Institutional causes, macroeconomic symmptoms: Volatility, crises and growth (No. 9124). Cambridge.

Adams, D., \& Tiesdell, S. (2012). Shaping places: urban planning, design and development. London: Routledge.

Amborse, P. (1986). Whatever Happened to Planning? London: Methuen.

Bagheri, A., \& Hjorth, P. (2007). Planning for Sustainable Development: A Paradigm Shift Towards a Process-Based Approach. Sustainable Development, 15(October 2006), 83-96.

Ball, M. (1983). Housing Policy and Economic Power. London: Mathuen.

Berrang-ford, L., Pearce, T., \& Ford, J. D. (2015). Systematic review approaches for climate change adaptation research. Regional Environmental Change, 15(2), 83-96. http://doi.org/10.1007/s10113-014-0708-7

Blewitt, J. (2014). Understanding sustainable development. London: Routledge.

Boddy, M. (1981). The property sector in late capitalism: the case of Britain, in Urbanization and Urban Planning in Capitalist Society. In M. Dear \& A. J. Scott (Eds.), Urbanization and Urban Planning in Capitalist Society. London: Routledge.

Bowler, D. E., Buyung-ali, L., Knight, T. M., \& Pullin, A. S. (2010). Landscape and Urban Planning Urban greening to cool towns and cities: A systematic review of the empirical evidence. Landscape and Urban Planning, 97(3), 147-155. http://doi.org/10.1016/j.landurbplan.2010.05.006

Bryman, A. (2012). Social Research Methods (Fourth Edi). Oxford: Oxford University Press.

Cadman, D., \& Austin-Crowe, L. (1978). Property Development. London: E. \& F. N. Spon.

Cassam, Q. (2009). Can the concept of knowledge be analysed? In P. Greenough \& D. Pritchard (Eds.), Williamson on Knowledge. Oxford: Oxford University Press.

Checker, M. (2011). Wiped Out by the "Greenwave": Environmental Gentrification and the Paradoxical Politics of Urban Sustainability. City \& Society, 23(2), 210-229. http://doi.org/10.1111/j.1548-744X.2011.01063.x.I

Chiu, R. L. H. (2004). Socio-cultural sustainability of housing: a conceptual exploration. Housing, Theory and Society, 21(2), 65-76.

Costanza, R., Cumberland, J. ., Daly, H., Goodland, R., \& Norgaard, R. B. (1997). An introduction to ecological economics. An introduction to ecological economics.

Costanza, R., \& Patten, B. C. (1995). Defining and predicting sustainability. Ecological Economics, $15,193-196$.

Craven, E. A. (1969). Private residential expansion in Kent 1956-1964: a study of pattern and process in urban growth. Urban Studies1, 6, 1-16.

Curran, W., \& Hamilton, T. (2012). Local Environment: The International Journal of Justice and Sustainability. Local Environment, 17(9), 1027-1042.

Doak, J., \& Karadimitriou, N. (2007). ( Re ) development, Complexity and Networks: A Framework for Research. Urban Studies, 44(2), 209-229.

Drewett, R. (1973). The developers: decision process. In P. Hall (Ed.), The Containment of Urban England. London: Allen and Unwin.

European Union. (2004). Urban Desig for Sustainability. Final Report of the Working Group on Urban Design for Sustainability to the European Union Expert Group on the Urban Environment. Vienna: Austrian Federal Ministry of Agriculture, Forestry, Environment and Water Management.

Filho, W. L. (2000). Dealing with misconceptions on the concept of sustainability. International Journal of Sustainability in Higher Education, 1(1), 9-19.

Giddens, A. (1984). The constitution of society: Introduction of the theory of structuration. Berkeley. http://scholar.google.com/scholar?start=20\&q=giddens+structuration\&hl=en\&as_sdt=0,5 
\#17

Glavič, P., \& Lukman, R. (2007). Review of sustainability terms and their definitions. Journal of Cleaner Production, 15, 1875-1885.

Gottdiener, M. (1994). Semiotics and postmodernism. In D. R. Dickens \& A. Fontana (Eds.), Postmodernism and social inquiry. Guilford Publications.

Hägerstrand, T. (1976). Innovation as a spatial process. IL: University of Chicago Press.

Harvey, D. (1982). The Limits to Capital. London: Blackwells.

Harvey, D. (1985). The Urbanisation of Capital. London: Blackwells.

Healey, P. (1991). Models of the development process : A review. Journal of Property Research1, $8(3), 219-238$.

Healey, P. (1992). An institutional model of the development process. Journal of Property Research, 9(1), 33-44. http://doi.org/10.1080/09599919208724049

Healey, P. (1999). Institutionalist Analysis, Communicative Planning, Shaping Places. Journal of Planning Education and Research, 19, 111-121. http://doi.org/10.1177/0739456X9901900201

Healy, P. (2007). Urban complexity and spatial strategies: towards a relational planning for our times. London: Routledge.

Holland, S., Ott, S. H., \& Riddiough, T. J. (2002). The role of uncertainty in investment: An examination of competing investment (Vol. 4307). Massachusetts: Massachusetts Institute of Technology.

Horton, J., Hadfield-Hill, S., \& Kraftl, P. (2015). Children living with "sustainable" urban architectures. Environment and Planning $A, \quad$ (47), 903-921. http://doi.org/10.1068/a140401p

Kaiser, E. J., \& Weiss, S. F. (1970). Public Policy and The Residential Development Process. Journal of the American Institute of Planners, 36(1), 30-37. http://doi.org/10.1080/01944367008977277

Kauko, T. (2017). Pricing and Sustainability of Urban Real Estate. London: Routledge.

Kemp, R., \& Martens, P. (2007). Sustainable Development: How to Manage Something That Is Subjective and Never Can Be Achieved? Suatainability: Science, Practice, \& Policy, 3(2), 110. http://doi.org/10.1080/15487733.2007.11907997

Kohlhepp, D. B. (2018). The Real Estate Development Matrix Presented at The American Real Estate Society Meetings.

Localism Act 2011 (2011). Retrieved http://www.legislation.gov.uk/ukpga/2011/20/pdfs/ukpga_20110020_en.pdf

Lombardi, D. R., Porter, L., Barber, A., \& Rogers, C. D. F. (2010). Conceptualising Sustainability in UK Urban Regeneration: A Discursive Formation. Urban Studies, (March 2016), 1-24. http://doi.org/10.1177/0042098009360690

Lowndes, V. (2010). The institutional approach. In D. Marsh \& G. Stoker (Eds.), Theories and methods in political science. Basingstoke: Palgrave.

Massey, D., \& Catalano, A. (1978). Capital and Land. London: Edward Arnold.

Matutinović, I. (2007). An Institutional Approach to Sustainability: Historical Interplay of Worldviews, Institutions and Technology. Journal of Economic Issues, XLI(December 2007), 4. http://doi.org/10.1080/00213624.2007.11507089

Miles, M. ., Berens, G., Weiss, M. ., \& Urban Land Institute. (1996). Real Estate Development: Principles and process. Washington: Urban Land Institute.

Næss, P. (2001). Urban Planning and Sustainable Development. European Planning Studies, 9(4), 503-524. http://doi.org/10.1080/09654310120049871

Özkaynak, B., Devine, P., \& Rigby, D. (2014). Operationalising Strong Sustainability : Definitions , Methodologies and Outcomes. Environmental Val, 13, 279-303.

Pearce, D., Markandya, A., \& Barbier, E. B. (1989). Blueprint for a Green Economy Submission to 
the Shadow Cabinet Quality of Life Policy Group. Routledge. http://doi.org/10.4324/9780203097298

Ramasubramanian, L. (2010). Geographic information science and public participation. Springer Science \& Business Media.

Ratcliffe, J., Stubbs, M., \& Shepherd, M. (2003). Urban planning and real estate development. London: Routledge.

Robinson, J. (2004). Squaring the circle? Some thoughts on the idea of sustainable development. Ecological Economics, 48, 369-384. http://doi.org/10.1016/j.ecolecon.2003.10.017

Šaparauskas, J., \& Turskis, Z. (2006). Evaluation of construction sustainability by multiple criteria methods. Technological and Economic Development of Economy, XII(4), 321-326.

Schreurs, J., \& Moulaert, F. (2014). Planning for sustainable development: lost in space? In Spatial Planning in Flanders/Belgium: challenges for policy, opportunities for society.

Squires, G., \& Heurkens, E. (2014). International Approaches to Real Estate Development. London: Routledge.

Tranfield, D., Denyer, D., \& Smart, P. (2003). Towards a Methodology for Developing EvidenceInformed Management Knowledge by Means of Systematic Review *. British Journal of Managementurnal of Management, 14, 207-222.

United Nations. (2016). Sustainable Development Goals. https://www.un.org/sustainabledevelopment/sustainable-development-goals/.

United Nations, Department of Economic and Social Affairs, \& Population Division. (2014). World Urbanization Prospects: The 2014 revision, Highlight. New York.

Victor, L. (2008). Systematic reviewing. Social Research Update, (54).

Vos, R. O. (2007). Defining sustainability: a conceptual orientation. Journal of Chemical Technology and Biotechnology, 82, 334-339. http://doi.org/10.1002/jctb

Voss, J. P., Bauknecht, D., \& Kemp, R. (2007). Reflexive governance for sustainable development. Edward Elgar Publishing.

Walker, S. (2012). Sustainable by design: Explorations in theory and practice. London: Routledge.

Wood, B. (2005). Towards innovative building maintenance. Structural Survey, 23(4), 291-297. http://doi.org/10.1108/02630800510630466

World Commision on Environment Development. (1987). Our Common Future. New York: Oxford University Press. 